$\underline{\text { Research article }}$

\title{
Prevalence of canine tick-borne haemoparasites in three Divisional Secretariat Divisions (Rambewa, Tirappane, and Galenbidunuwewa) in the Anuradhapura district, Sri Lanka
}

\author{
D Weerathunga $^{1}$, AAmarasinghe $^{1}$, D Iddawela $^{1}$, \\ S Wickramasinghe ${ }^{1}$ \\ Sri Lankan Journal of Infectious Diseases 2019 Vol.9 (2):111-119 \\ DOI: http://doi.org/10.4038/sljid.v9i2.8254
}

\begin{abstract}
Introduction and Objectives: Ticks act as the vector for transmission of many parasitic pathogens. Several tick-borne haemoparasite infections are widespread among canines in tropical countries. However, information is scarce regarding canine tick-borne infections in Sri Lanka. The present study was therefore carried out to identify the canine tick-borne haemoparasite species and thereby assess their prevalence in three Divisional Secretariat divisions in the Anuradhapura district.
\end{abstract}

Materials and methods: Blood samples were collected from dogs in three Divisional Secretariat (DS) divisions namely, Rambewa, Tirappane, and Galenbindunuwewa in the Anuradhapura district, Sri Lanka. From each blood sample, two thin smears were prepared and stained with Giemsa. Stained slides were subsequently examined with a light microscope to detect haemoparasites.

Results: Out of 319 blood samples, 139 were positive for haemoparasites. Of the positives, $51.61 \%$ were from Rambewa, $40.47 \%$ were from Galenbindunuwewa and $38.88 \%$ were from Tirappane. Three haemoprotozoan species, Hepatozoon canis, Babesia gibsoni, Babesia canis and one bacterial species, Ehrlichia canis were morphologically identified in the present study.

Conclusions: Comparatively, the prevalence of ehrlichiosis (20.06\%) and babesiosis (16.29\%) were high in three DS divisions compared to the prevalence of $H$. canis infection (1.56\%). The prevalence of the haemoprotozoan infections was significantly different among thee DS divisions

${ }^{1}$ Department of Parasitology, Faculty of Medicine, University of Peradeniya, Sri Lanka Address for correspondence: Dr S Wickramasinghe, Department of Parasitology, Faculty of Medicine, University of Peradeniya Telephone: +94770074544 Email: susijijp@yahoo.co.jp

https://orcid.org/0000-0003-2046-1093

Received 13 June 2019 and revised version accepted 6 September 2019

(c) (i)

This an open-access article distributed under the terms of the Creative Commons Attribution License, which permits unrestricted use, distribution, and reproduction in any medium, provided the original author and source are credited. 
$(\mathrm{P}<0.01)$. Co-infections among dogs suggest that the same vector may be involved in transmitting different infections.

Keywords: Haemoprotozoa, Hepatozoon canis, Babesia gibsoni, Babesia canis, Ehrlichia canis

\section{Introduction}

Canine tick-borne diseases are a major health problem among dogs in tropical and subtropical countries. Ticks have the capability to successfully transmit disease agents such as viruses, bacteria andprotozoa. ${ }^{1}$ Babesiosis, ehrlichiosis and hepatozoonosis are some common tick-borne parasitic infections in dogs. ${ }^{2,3}$ These infections can occur in dogs due to the transmission of haemoparasites by several tick species or by the same species. ${ }^{4}$ For example, the main vector of $B$. canisvogeli, $H$. canis, and E. canis is the brown dog tick (Rhipicephalus sanguineus). ${ }^{5}$

Babesiosis is caused by intraerythrocytic piroplasms of the genus Babesia. It is a common disease among domestic and wild canines. ${ }^{6}$ Ehrlichia is an alphaproteobacterium belonging to the family Ehrlichiaceae. E. canis and E. ewingii cause tropical canine pancytopenia and canine granulocytic ehrlichiosis respectively. ${ }^{7}$ E. canis causes severe clinical signs in dogs compared to the other species. E. chaffeensis causes infections in both humans and dogs. ${ }^{9}$ Canine hepatozoonosis is a systemic disease caused by the protozoan H. canis (Apicomplexa, Hepatozoidae). It is transmitted by the dog tick $R$. sanguineus. H. canis is found in Africa, Southern Europe, Asia, Australia and America. ${ }^{7}$ Ticks acquire the pathogen by feeding on an infected host. Transstadial transmission from the nymph to the adult stage can occur.

Previous studies have determined the prevalence of canine haemoparasites in Sri Lanka. H. canis was first identified in 1961 in Sri Lanka. ${ }^{9}$ In 2017, cases of acute hepatozoonosis, characterized by neurological symptoms, ataxia or paresis, emaciation and anaemia was detected. ${ }^{10}$ An early study has determined the prevalence of canine ehrlichiosis in Sri Lanka based on conventional examination of stained blood smears. ${ }^{11}$ A study carried out to determine the prevalence of canine vector-borne diseases in the Western Province identified the prevalence of both single and mixed infections among dogs. ${ }^{12}$ However, there is a relative paucity of studies on the prevalence of canine tick-borne infections in Sri Lanka. In the present study, our objectives were to identify the canine tick-borne haemoparasite species and assess their prevalence in three Divisional Secretariat divisions in the Anuradhapura district.

\section{Materials and Methods}

\section{Study area}

This study was conducted in three Divisional Secretariat (DS) divisions: Rambewa, Tirappane, and Galenbindunuwewa in the Anuradhapura district, Sri Lanka (Figure 1). 


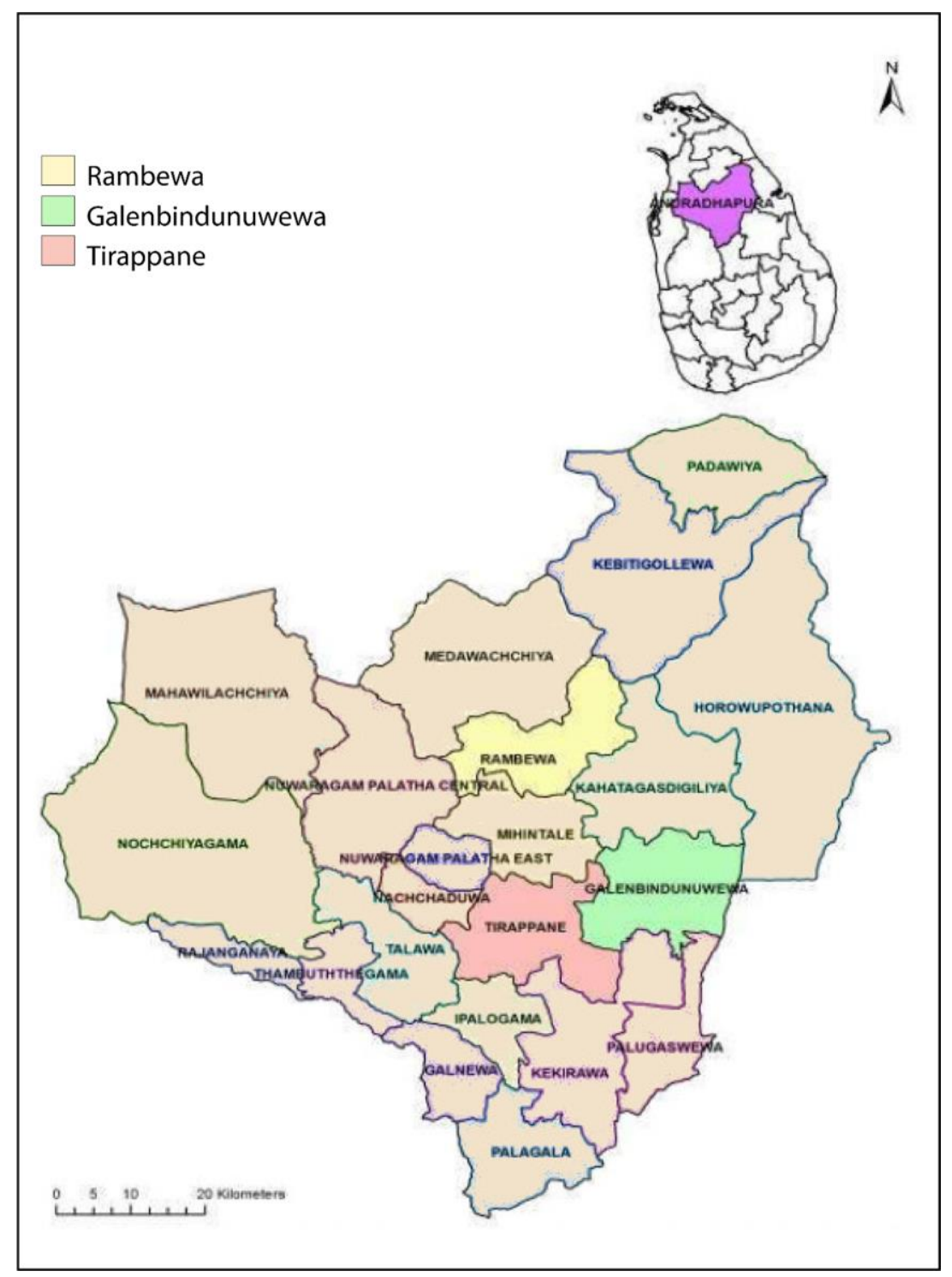

Figure 1: Map of Anuradhapura District Divisional Secretariat (DS) Divisions.

The three sampling sites; Rambewa, Galenbindunuwewa and Tirappane DS divisions are highlighted.

\section{Sample collection}

The sample size was calculated using the Creative Research Systems survey software (http://www.surveysystem.com/sscalc.htm). The calculated sample size was 375 (dog population was about 14,698 and the confidence interval was 95\%). Blood samples were collected from April 2014 to July 2014 at the prophylactic anti-rabies vaccination and sterilization centers. Blood samples (1-2 ml) were collected into ethylenediaminetetraacetic acid (EDTA) tubes. Samples were stored at $4{ }^{\circ} \mathrm{C}$ and dispatched to the Department of Parasitology, Faculty of Medicine, University of Peradeniya, Sri Lanka to carry out the laboratory investigations. 


\section{Microscopic examination}

From each blood sample, 2-3 thin smears were prepared and stained with Giemsa according to the method described in a previous study. ${ }^{13}$ Smears were examined with a light microscope (Carl Zeiss $^{\mathrm{TM}}$ PrimoStar $^{\mathrm{TM}}$, Germany) under oil immersion $(\times 1000)$ to identify the haemoparasites. $H$. canis was identified by observing the gamonts with an ellipsoidal, brick-like shape inside the cytoplasm of the neutrophils. ${ }^{14}$ In the erythrocytes, $B$. canis was identified by the morphology of merozoites described in a previous study. ${ }^{15}$ Detection of $B$. gibsoni in the infected erythrocytes was carried out according to the morphological features described by Lempereur et al.(2014). ${ }^{16} E$. canis was identified by the round shape and purple colour morulae in the cytoplasm of lymphocytes. $^{17}$

\section{Statistical analysis}

Chi square test was conducted in $\mathrm{R}^{18}$ to identify whether the prevalence of the haemoprotozoan infections was significantly different among the three DS divisions.

\section{Results}

\section{Sample collection}

All the dogs included in this study were females with an average age of 3 years and were asymptomatic. A total of 319 blood samples were collected from Rambewa (124), Tirappane (108) and Galenbindunuwewa (87) DS divisions. Of those, 312 were obtained from stray dogs and 7 were from pet dogs.

\section{Microscopic examination}

Four haemoparasites namely E. canis, H. canis, B. canis and B. gibsoni were identified by microscopic examination (Figure 2).

\section{Prevalence in the three DS divisions}

The prevalence of infection differed significantly between the divisions. $\left(\chi^{2}=18.47, \mathrm{df}=6, \mathrm{P}<0.01\right)$. In Rambewa DS division, the number of mixed infections was high (Table 1). There were no $H$. canis single infections. In Galenbindunuwewa, H. canis with B. gibsoni, B. gibsoni with E. canis were the only mixed infections detected. In Tirappane the only mixed infection detected was $B$. gibsoni with E. canis. However, no B. canis infections were identified in Tirappane DS division.

\section{Overall prevalence of the haemoparasites}

When considering the percentage overall prevalence in the three DS divisions, of the positive samples, the highest prevalence $(51.61 \%)$ was from Rambewa and the lowest $(38.88 \%$ ) from Tirappane (Table 1). Among haemoparasites, Rambewa DS division had a significantly high number of E. canis infections. The highest number of $B$. gibsoni infections was found in the Tirappane DS division. H. canis was present in all three DS divisions. B. canis presented in Rambewa and Galenbindunuwewa DS divisions but was not present in the Tirappane DS division (Table 1). 

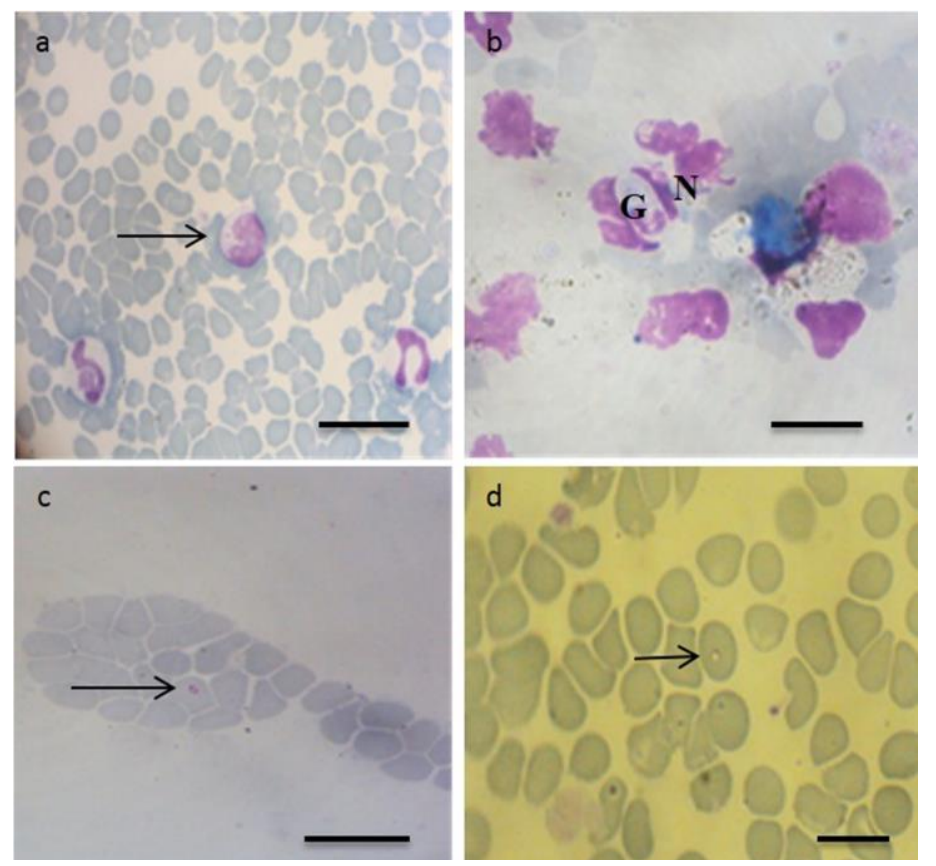

Figure 2: Haemoparasite species identified in the canine blood samples.

\author{
a: Morulae (arrow) of E. canis in the lymphocytes. \\ b: Gamont of H. canis in the neutrophil (G-Gamont and N-Nucleus of \\ the neutrophil). \\ c: Pear shaped B. canis merozoite (arrow) in the red blood cell. \\ $\mathrm{d}$ : Signet ring shaped B. gibsoni merozoite (arrow) in the red blood cell \\ (Scale bar in each figure represents $20 \mu \mathrm{m}$ ).
}

The prevalence of each species was determined by examining all the positive samples. $H$. canis was present in $1.56 \%$ of samples as a single infection. Another $1.56 \%$ had mixed infections of $H$. canis with both E. canis and B. gibsoni. In $15.04 \%$ of the samples, B. gibsoni was detected as a single infection. B. gibsoni showed mixed infections in $5.05 \%$ of samples either with $E$. canis, $B$. canis or H. canis. In $1.25 \%$ of samples B. canis was observed as a single infection. Another $1.25 \%$ had mixed infections of B. canis and E. canis. In $20.05 \%$ of samples, E. canis was detected as a single infection. Furthermore, $4.38 \%$ had E. canis mixed infections with one or more of the other three species. 
Table 1: Prevalence of single and mixed infections of canine haemoparasites in three Divisional Secretarial divisions in the Anuradhapura district

\begin{tabular}{|c|c|c|c|c|}
\hline Type of infection & $\begin{array}{c}\text { Rambewa } \\
n=124\end{array}$ & $\begin{array}{c}\text { Galenbindunuwewa } \\
n=87\end{array}$ & $\begin{array}{c}\text { Tirappane } \\
\mathbf{n}=108\end{array}$ & $\begin{array}{l}\text { Overall prevalence } \\
n=319\end{array}$ \\
\hline \multicolumn{5}{|l|}{ Single infections } \\
\hline B. canis & $2(1.61 \%)$ & $2(2.29 \%)$ & $0(0.00 \%)$ & $4(1.25 \%)$ \\
\hline B. gibsoni & $13(10.48 \%)$ & $11(12.64 \%)$ & $24(22.22 \%)$ & $48(15.04 \%)$ \\
\hline E. canis & $35(28.22 \%)$ & $16(18.39 \%)$ & $13(12.03 \%)$ & $64(20.06 \%)$ \\
\hline H. canis & $0(0.00 \%)$ & $2(2.29 \%)$ & $3(2.77 \%)$ & $5(1.56 \%)$ \\
\hline \multicolumn{5}{|l|}{ Mixed infections } \\
\hline H. canis + E. canis & $1(0.80 \%)$ & $0(0.00 \%)$ & $0(0.00 \%)$ & $1(0.31 \%)$ \\
\hline H. canis + B. gibsoni & $1(0.80 \%)$ & $2(2.24 \%)$ & $0(0.00 \%)$ & $3(0.94 \%)$ \\
\hline $\begin{array}{l}\text { H. canis }+ \text { E. canis }+ \\
\text { B. gibsoni }\end{array}$ & $1(0.80 \%)$ & $0(0.00 \%)$ & $0(0.00 \%)$ & $1(0.31 \%)$ \\
\hline B. canis + B. gibsoni & $1(0.80 \%)$ & $0(0.00 \%)$ & $0(0.00 \%)$ & $1(0.31 \%)$ \\
\hline B. gibsoni+ E. canis & $7(5.64 \%)$ & $1(1.14 \%)$ & $1(0.92 \%)$ & $9(2.82 \%)$ \\
\hline B. canis + E. canis & $3(2.41 \%)$ & $0(0.00 \%)$ & $0(0.00 \%)$ & $3(0.94 \%)$ \\
\hline Total prevalence & $64(51.61 \%)$ & $34(39.08 \%)$ & $41(38.88 \%)$ & $139(43.57 \%)$ \\
\hline
\end{tabular}

$\mathrm{n}$ : number of samples collected in each DS division

\section{Discussion}

In this study, the prevalence and distribution of canine vector-borne infections in three DS divisions in the Anuradhapura district were investigated. There were $43.88 \%$ dogs positive for haemoparasites indicating infections caused by this group of parasites are common among dogs in the localities examined. Single infections were found in $37.93 \%$ of dogs. This is higher than a previous report on dogs in the Western Province (29.15\%). ${ }^{11}$ Mixed infections were detected in $5.95 \%$ of dogs examined which agrees with the previous study done by Kumara et al. in 2013. ${ }^{12}$ Mixed infections with only two pathogens were observed in 5.6\% dogs. Similar results have been documented in the Western Province of Sri Lanka. ${ }^{11}$

This study reports a high prevalence of E. canis infections (20.06\%) compared to the previously reported prevalence of $14 \%$ in dogs in the Western Province. ${ }^{12}$ The prevalence of B. canis $(1.25 \%)$ and $B$. gibsoni $(15.04 \%)$ reported in this study were also higher than previously reported in the Western Province. ${ }^{11}$ The prevalence of $H$. canis $(1.56 \%)$ was lower than in the Western Province $(8.57 \%){ }^{12}$

A study conducted in Nigeria has shown a high rate of mixed infection (37\%) that was caused by the same haemoparasite species identified in this sutdy. ${ }^{19}$ E. canis infection can predispose dogs to opportunistic pathogens, such as B. canis and H. canis. ${ }^{5}$ Having multiple tick-transmitted infections in dogs is associated with severe and fatal conditions. ${ }^{5}$ The Brown dog tick $(R$. sanguineus) is the main vector transmitting the pathogens found in mixed infections. ${ }^{20}$ The prevalence of this tick species is common among domestic animals in the dry zone. ${ }^{21}$ It can therefore be suggested that any control measures taken to eradicate this tick species can reduce more than one type of haemoparasitic infection found in dogs. All the haemoparasite infections identified are known to be asymptomatic. ${ }^{22-25}$ However, in some dog breeds, B. gibsoni infection can be symptomatic. ${ }^{26}$ 
Differences in the distribution of vector-borne diseases are largely determined by the geographical distribution and local density of their arthropod vectors. Furthermore, environmental changes have a direct impact on the geographical distribution of arthropods, size of their population and their ability to act as a vector to transmit diseases. ${ }^{27,28}$ Future studies are required to examine the putative tick vectors and their population characteristics. Results obtained during this study would be useful for the accurate design of such investigations. We would suggest implementation of coordinated control and prevention programs of canine tick-borne diseases with the help of veterinary and public authorities. Prophylactic measures, including the use of acaricides and insecticides can be used to control the vectors. ${ }^{29}$ These control measures are necessary to prevent any possible zoonotic transmission.

\section{Limitations of the study}

Blood samples were collected only at the prophylactic anti-rabies vaccination and sterilization centers. However, the expected numbers of dogs were not brought to these centers. As a result, the number of samples collected are less than the calculated sample size. Any background information about these dogs was not considered. Haemoparasite species were identified using morphological characteristics. Species identities should be further confirmed using molecular techniques.

\section{Conclusions}

This study was carried out on tick-borne canine haemoparasitic infections in three DS divisions in Anuradhapura district, Sri Lanka. Comparatively, the prevalence of ehrlichiosis and babesiosis was high in the three DS divisions. The prevalence of $H$. canis was low. Co-infections among dogs suggest that the same vector may be involved in transmitting different infections.

Acknowledgments: Authors would like to acknowledge the Veterinary Surgeons of Animal Health Organization for the support extended to collect samples. Special thanks to the technical staff of the Department of Parasitology, Faculty of Medicine, University of Peradeniya for their assistance during the laboratory work.

Funding: This research did not receive any specific grant from funding agencies.

Conflict of interests: The authors declare that they have no conflicts of interests.

Ethical statement: This study was approved by the Institutional Animal Ethics Committee of the Postgraduate Institute of Science (PGIS), University of Peradeniya, Sri Lanka.

\section{References}

1. Shaw SE, Day MJ, Birtles RJ, et al. Tick-borne infectious diseases of dogs. Trends Parasitol 2001; 17(2):74-80. doi: https://doi.org/10.1016/S1471-4922(00)01856-0

2. Uilenberg G. International collaborative research: significance of tick-borne hemoparasitic diseases to world animal health. Vet Parasitol 1995; 57(1-3):19-41. doi: https://doi.org/10.1016/03044017(94)03107-03108

3. Kidd L, Breitschwerdt EB. Transmission times and prevention of tick-borne diseases in dogs. Compend Contin Educ Vet 2003; 25(10):742-751.No doi. 
4. Chomel B. Tick-borne infections in dogs-an emerging infectious threat. Vet Parasitol 2011; 179(4):294-301. doi: https://doi.org/10.1016/j.vetpar.2011.03.040

5. Gal A, Harrus S, Arcoh I, et al. Coinfection with multiple tick-borne and intestinal parasites in a 6week-old dog. Can Vet J 2007; 48(6):619. PMID: 17616060

6. Ayoob AL, Hackner SG, Prittie J. Clinical management of canine babesiosis. J Vet Emerg Crit Care 2010; 20(1):77-89. doi: https://doi.org/10.1111/j.1476-4431.2009.00489.x

7. Skotarczak B. Canine ehrlichiosis. Ann Agric Environ Med. 2003;10(2):137-142. No doi.

8. Irwin PJ. Companion animal parasitology: a clinical perspective. Int J Parasitol 2002; 32(5):581-593. doi: https://doi.org/10.1016/S0020-7519(01)00361-00367

9. Dissanaike AS. Hepatozoon canis infection in dogs in Ceylon. Ceylon Veterinary Journal 1961; 1X,144-145. No doi.

10. Atapattu U, Dissanayake DA, Silva ID, Bulumulla DG, et al. Acute heaptozoonosis caused by Hepatozoon canis in dogs in Sri Lanka. Sri Lanka Veterinary Journal 2017; 64(1A):8-11. doi: http://doi.org/10.4038/slvj.v64i1A.19

11. MacGaughey CA, Seneviratne P, Mahalingam S. Rickettsiosis of dogs in Ceylon. Ceylon Veterinary Journal 1962; X, 82-87. No doi.

12. Kumara KAAS, Wickramasinghe S, Kulanayake SMP, et al. Molecular identification and prevalence of vector-borne infections in dogs from Western Province in Sri Lanka. Symp. $2^{\text {nd }}$ Annual Conference and Scientific sessions of Sri Lankan Society for Microbiology (SSM), 25 ${ }^{\text {th }}$ October 2013. PGIS, University of Peradeniya1, 25.

13. Warhurst DC, Williams JE. Laboratory diagnosis of malaria. J Clin Pathol 1996; 49(7):533. doi

14. Baneth G, Samish M, Shkap V. Life cycle of Hepatozoon canis (Apicomplexa: Adeleorina: Hepatozoidae) in the tick Rhipicephalus sanguineus and domestic dog (Canis familiaris). $J$ Parasitol 2007; 93(2):283-299. PMID:17539411

15. Huber D, Beck A, Anzulović Ž, et al. Microscopic and molecular analysis of Babesia canis in archived and diagnostic specimens reveal the impact of anti-parasitic treatment and postmortem changes on pathogen detection. Parasit Vectors 2017; 10(1):495. doi: 10.1186/s13071-017-2412-1

16. Lempereur L, Beck R, Fonseca I, et al. Guidelines for the detection of Babesia and Theileria parasites. Vector Borne Zoonotic Dis 2017; 17(1):51-65. doi: 10.1089/vbz.2016.1955

17. Hildebrandt PK, Conroy JD, McKee AE, et al. Ultrastructure of Ehrlichia canis. Infect Immun. 1973; 7(2):265-271. PMID: 4735376

18. R Core Team 2019. R: language and environment for statistical computing. R Foundation for Statistical Computing, Vienna, Austria. https://www.R-project.org/.

19. Kamani J, Baneth G, Mumcuoglu KY, et al. Molecular detection and characterization of tick-borne pathogens in dogs and ticks from Nigeria. PLoS Negl Trop Dis 2013; 7(3):e2108.

doi: https://doi.org/10.1371/journal.pntd.0002108

20. Baneth G, Mathew JS, Shkap V, et al. Canine hepatozoonosis: Two disease syndromes caused by separate Hepatozoon spp. Trends Parasitol 2003;19:27-31. doi: https://doi.org/10.1016/S14714922(02)00016-8

21. Liyanaarachchi DR, Rajakaruna RS, Dikkumbura AW, et al. Ticks infesting wild and domestic animals and humans of Sri Lanka with new host records. Actatropica 2015; 142:64-70.

doi: https://doi.org/10.1016/j.actatropica.2014.11.001

22. Labarthe N, Barbarini O, Mckee W, et al. Serologic prevalence of Dirofilaria immitis, Ehrlichia canis, and Borrelia burgdorferi infections in Brazil. Vet Ther 2003; 4:67-75. PMID:12756637

23. Eiras DF, Basabe J, Scodellaro CF, et al. First molecular characterization of canine hepatozoonosis in Argentina: evaluation of asymptomatic Hepatozoon canis infection in dogs from Buenos Aires. Vet Parasitol 2007; 149:275-279. doi: https://doi.org/10.1016/j.vetpar.2007.07.010

24. Jefferies R, Ryan UM, Jardine J, et al. Blood, bull terriers and babesiosis: further evidence for direct transmission of Babesia gibsoni in dogs. Aust Vet J 2007; 85:459-463.

doi:10.1111/j.1751-0813.2007.00220.x 
25. Ćoralić A, Gabrielli S, Zahirović A, et al. First molecular detection of Babesia canis in dogs from Bosnia and Herzegovina. Ticks and Tick Borne Dis 2018; 9:363-368.

doi: https://doi.org/10.1016/j.ttbdis.2017.11.013

26. Imre M, Farkas R, Ilie MS, et al. Survey of babesiosis in symptomatic dogs from Romania: Occurrence of Babesia gibsoni associated with breed. Ticks and Tick Borne Dis. 2013; 4:500-502 doi: http://dx.doi.org/10.1016/j.ttbdis.2013.06.006

27. Patz JA, Graczyk TK, Geller N, et al. Effects of environmental change on emerging parasitic diseases. Int J Parasitol 2000; 30(12-13):1395-1405. doi: https://doi.org/10.1016/S0020-7519(00)00141-00147

28. Beugnet F, Marié JL. Emerging arthropod-borne diseases of companion animals in Europe. Vet Parasitol 2009; 163(4):298-305. doi: https://doi.org/10.1016/j.vetpar.2009.03.028

29. Beugnet F, Franc M. Insecticide and acaricide molecules and/or combinations to prevent pet infestation by ectoparasites. Trends Parasitol 2012;28(7):267-279. doi: https://doi.org/10.1016/j.pt.2012.04.004 